\section{D.P. Veldsman}

Prof. D.P. Veldsman,

Systematic and

Historical Theology,

Faculty of Theology

and Religion,

University of Pretoria

Email: danie.veldsman@

up.ac.za

ORCID: https://orcid. org/0000-0002-87342171

DOI: http://dx.doi. org/10.18820/23099089/

actat.v40i1.10

ISSN 1015-8758 (Print)

ISSN 2309-9089 (Online)

Acta Theologica 2020

40(1):157-158

Date Published:

17 June 2020

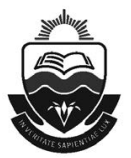

Published by the UFS

http://journals.ufs.ac.za/index.php/at

(C) Creative Commons

With Attribution (CC-BY)

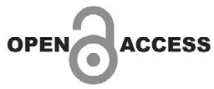

\section{BOOK REVIEW}

\section{THEOLOGY IN AN AGE OF CONTINGENCY}

Hermans, C.A.M. \& Schoeman, K. (eds). Series: International Practical Theology 21. (Zürich: LIT Verlag, 2019), 193 pp. ISBN 978-3-643-91108-7 (pb). €34.90. ISBN 978-3-643-96108-2 (pdf)

Contingency as concept represents an actual and relevant topic, which the authors address as a challenge in the $21^{\text {st }}$ century from the perspective of Practical Theology. The two editors, Hermans and Schoeman, are affiliated to Radboud University in The Netherlands and to the University of the Free State in South Africa, respectively.

In the Introduction, they briefly indicate how they understand the concept and the background to the book, namely as the result of a research project related to the inaugural lecture of Hermans as extraordinary professor in Practical Theology and Missiology at the University of the Free State. The opening chapter is an elaborated version of his inaugural address and is structured according to the four tasks of Practical Theology, namely theological-normative, hermeneutic, pragmatic and empirical. As responses to the opening chapter, the ensuing eight chapters critically reflect on doing theology in an age of contingency, and are structured according to the four tasks.

The theological-normative task, in relation to the challenge of contingency, is addressed in three chapters of the first section of the book, namely Rian Venter's Re-imagining God in an era of contingency (Chapter 2); Jaco Dreyer's Practical Theology and the human person in an age of 
contingency (Chapter 3), and Jan-Albert van den Berg's Contingencies, the $4^{\text {th }}$ Industrial Revolution and theologies of practices (Chapter 4). Venter questions Hermans' conceptualisation of contingency; Dreyer positions the concept of contingency between the rejection of essentialism and postmodernism, whereas Van den Berg explores the anthropological-theological understanding of human capability in the context of humanness. The interpretative task of Practical Theology is addressed in Chapters 5 and 6, respectively, by Kobus Kok in his John Chrysostom and "Knowing God as debtor-friend': An event-hermeneutical reading, and Frederick Marais in his Discernment as generative dialogue. A constructive proposal for the challenges of missional corporate discernment in an age of contingency. The latter explores the practice of discernment and generative dialogue as an event where new possibilities of God's future can emerge, whereas the former explores the theological significance of God's free gift of grace to human beings. In the next three chapters, the pragmatic and empirical tasks of Practical Theology are addressed by Kobus Schoeman (Chapter 7) in his Shifting strategies in the study of South African congregations in an age of contingency; Joseph Pali (Chapter 8) in his Leadership in an age of contingency, and Eugene Baron (Chapter 9) in his The struggle to be an agent and to facilitate agency at the same time: A missiological perspective. These three chapters focus on contemporary ecclesiological shifts in the South African society, changes in leadership styles, as well as "encounterology" and the pastoral cycle, respectively. In the final chapter entitled Everything can change. A response to my conversation partners, Hermans engages with the authors' contributions.

Although the depth of discussion and the engagement with Hermans in the various contributions varies greatly, the overall impression of Theology in an age of contingency is that of a very readable contribution to an extremely slippery and difficult philosophical concept. As such, it is worth taking the engagement with Hermans and contingency from a South African practicaltheological perspective in this book seriously. It is, however, a pity that the publisher did not take great care in the orthographic set-up of the publication with a great number of inconsistent references and referencing (for example, Zie; pp; coram deo) and even spelling mistakes (for example, Moltman; Germen). A list of contributors as well as publications by LIT Verlag are included at the end of the book (pp. 191-193). 